This item was submitted to Loughborough's Research Repository by the author.

Items in Figshare are protected by copyright, with all rights reserved, unless otherwise indicated.

\title{
Introduction: governing through diversity
}

PLEASE CITE THE PUBLISHED VERSION

PUBLISHER

Palgrave Macmillan

VERSION

AM (Accepted Manuscript)

PUBLISHER STATEMENT

This work is made available according to the conditions of the Creative Commons Attribution-NonCommercialNoDerivatives 4.0 International (CC BY-NC-ND 4.0) licence. Full details of this licence are available at: https://creativecommons.org/licenses/by-nc-nd/4.0/

\section{LICENCE}

CC BY-NC-ND 4.0

\section{REPOSITORY RECORD}

Matejskova, Tatiana, and Marco Antonsich. 2019. "Introduction: Governing Through Diversity". figshare. https://hdl.handle.net/2134/17937. 


\section{Introduction: Governing through Diversity}

\section{Tatiana Matejskova \& Marco Antonsich}

It has become hard to avoid "diversity" today, especially in the global north. Organizations of all kinds feel compelled to have diversity plans and employ diversity practitioners. Increasing numbers of employees in many sectors are required to undergo diversity training. In public discourse likewise diversity is invoked regularly and in an increasing number of governmental arenas, from education through social work to the private sector (Puwar, 2004). In many countries, it has become in fact a 'central policy injunction' (Swan \& Fox, 2010, p. 570). In the EU, promotion of societal diversity and diversity mainstreaming now belong to the key goals of the Union (Kraus, 2014; Vertovec, 2012). Academia has, in a similar fashion, become embroiled in this new 'normative meta-narrative' (Isar, 2006, p. 1). In addition to the field of diversity management, that has existed within the orbit of workplace and management studies for quite some time, diversity studies has been emerging over the last decade as the interdisciplinary field covering much of what previously fell under migration and multiculturalism studies. An everincreasing number of teaching and research positions, calls for papers and research institutes, pre-fixed with the very term "diversity" attests to this transformation. Through all of this, diversity has assumed a status of a social good that no sensible person could disagree on.

So what are we to make of this 'turn to diversity' (Ahmed \& Swan, 2006, p. 96) in contemporary governance? At some level it could be argued that it reflects a long overdue recognition by these various actors of the actual linguistic, religious and broadly "ethnic" diversification in contemporary societies. Such an argument, however, assumes that diversity is a "natural" 
manifestation of differentiation (Cooper, 2004). It thus paves way to a reification of diversity as an innocuous, neutral term that simply describes actual social reality. And while the 'apparent descriptiveness is central to diversity's "normative character" as a value' (Titley \& Lentin, 2008, p. 11), we suggest that contemporary "diversity" is something quite different. The title of this collection already gives a hint: it namely speaks of governance through rather than of diversity. The through in this expression signals that diversity works as a very specific and distinct way through which social heterogeneity is problematized and governed in contemporary societies, especially in the global north. The through thus indicates that diversity does not somehow exist prior to or apart from governance and politics as the other, more common expression "governance of diversity" implies. Instead, diversity is today constructed as a problematic that needs to be understood, managed, acted upon, celebrated, considered, rethought and so on. This is in fact often the only thing that the incredibly varied, often incoherent and at times contradictory discursive and non-discursive practices, programs and policies attached to the thing-called-diversity have in common. This is similarly the case for the varied research on diversity. In order to start making sense of this heterogeneity, in this introduction we suggest that diversity be understood as a dispositif. Viewing diversity thus also allows us to consider all the entries into research on diversity that tend to remain isolated within one analytical plane, as belonging to one of the three analytical fields of diversity we identify: ideational, technical and the field of actual social relations.

In the first part of this introduction, we first briefly outline the development of critical diversity research. We then follow with an introduction of diversity as a dispositif. The second part introduces chapters gathered in this volume and the contributions they make within each of the 
three fields. We conclude with a summary of common themes and points made by the authors gathered here, highlighting in particular the need for a more explicitly spatial approach to diversity in the future research.

\section{From diversity management to critical diversity studies}

It was the organizational and business management studies that gave diversity its start, albeit with a rather positivist conceptualization as 'a set of rare, valuable and difficult to imitate resources' that could bring greater efficiency to companies and organizations if it was managed well (Zanoni et al., 2010, p. 11). Since the turn of the century this discipline has, however, given birth to critical diversity scholarship. Moving beyond the examination of presumed benefits that diverse labor force brings, scholars have in particular questioned the prevalent tendency to treat identities as fixed and distinct independent variables and to reify inadequate conceptualizations of power (Zanoni et al., 2010). Stressing that diversity is always socially (re)produced, diversity management is now understood - at least at times - to work to contain potential political antagonism of minorities, or reify class differentials between management and employees (for example Zanoni \& Janssens, 2004; Swan, 2009). Cautious of overreliance on the official diversity documents, researchers have recently called for more robust empirical investigations of how diversity gets actually "taken up" and experienced in the everyday organizational practice not only by diversity practitioners, but also by employees and managers (for example Zanoni \& Janssens, 2007; Tatli, 2011; Ahmed, 2007). Diversity is thus becoming explored more as, both, a ‘dynamic social practice' (Zanoni et al., 2010, p.18), and, importantly, as one of 'concepts-inthe-making' (Ostendorp \& Steyaert, 2009, p. 375). 
Scholars analyzing diversity from the angle of migration and identity studies have often remarked upon the conceptual instability of "diversity". That diversity remains deployed in vague and ambiguous ways in politics (Lentin \& Titley, 2008; Herring \& Henderson, 2011) as well as by broad public (Bell \& Hartmann, 2007) could be in fact seen as implicitly questioning the extent to which the turn towards diversity has been underwritten by 'a fundamental sensitizing process' to the issues of difference (Vertovec, 2012, p. 305). But more importantly, critiques of diversity as a floating signifier - the fact that it can mean almost anything to anyone - stress the lack of social justice-orientated deployments of diversity in current political contexts (for example Rodrigues-Garcia, 2010; Herring \& Henderson, 2011). While diversity politics is by some understood as a strand of critical social thought on identity and equality imbued with a commitment to anti-racism and social equity (for example Cooper, 2004), many critical analyses of actual diversity governance dispute this.

The fate that "difference" met, so to speak, when "diversity" got on the scene, plays a crucial role in such arguments. Diversity is namely seen as having converted difference into something 'largely aesthetic, politically and morally neutral' (Eriksen, 2006, p. 16), and even potentially more pleasurable (Ahmed, 2007). The problem is that diversity 'individuates difference', as clear from diversity management's focus on the recognition and value of an individual rather than social-group difference (Ahmed \& Swan, 2006, p. 96). This in turn often obfuscates and even 'exacerbate[s] structural causes of inequality' (Jones, 2006, p. 145). One could even argue that the very term of diversity is concealing inequality, since it - unlike some of the prior terminologies in management, including equal opportunities in the UK or affirmative action - 
does not mention or even allude to equity. Rather than being related to 'reflective identity politics', diversity is aligned with the market (Kraus, 2012, p. 3; see also Eriksen, 2006). And furthermore, by promoting the understanding of diversity as a 'mosaic' diversity governance 'inscribes difference within a sameness grid' (Swan, 2009, p. 77), flattening differences out as more or less all alike.

Yet wholesale rejection of diversity, as for example just 'a cost-free form of politics attuned to the needs of late capitalist, consumer societies' (Titley \& Lentin, 2008, p. 9), seems overly teleological. Even if one sees diversity discourse as a hegemonic one, it does not mean it is uncritically appropriated (Zanoni et al., 2010). Elaine Swan \& Stephen Fox (2010) observe that the critique of diversity governance has been plagued by a strong dualism of "good" versus "bad". This does not allow for the possibility of seeing potentially also progressive forces at work within "bad" institutions or policies. Rejecting simplistic accounts of either co-optation into, or resistance against the "badness" of diversity management, they instead suggest that discourse of diversity should be seen as a discursive resource that practitioners can use to different effect' (Swan and Fox, 2010, p. 583). And they do so, at least some times, as Sara Ahmed (2007, p. 238) showed in her study of practitioners in higher education who use the term strategically - instead of a previously overused and, in words one of them, 'tired' term equity - to promote their anti-racist and gender equality agendas. Thus while diversity discourse does not evoke commitment to redistribution and instead often 'neutralises histories of antagonism and struggle' (Ahmed \& Swan, 2006, p. 96), the very 'interpretive elasticity’ of diversity (Lees, 2003, p. 622) and the fact that interpretation is always a 'performative act' (Ostendorp \& Steyeart, 2009, p. 375) can also make room for diversity practitioners to imbue their concrete practice with 
other objectives. We concur with Sara Ahmed that "if "diversity" does not have any necessary meaning, or if diversity is “cut off” from a specific referent, then it does not necessarily work only to conceal inequalities' (2007, p. 237). This point does not only imply the need for more research on how diversity gets apprehended, interpreted, operationalized, evoked and practiced. It also ushers in governmentality-inspired perspectives for critical diversity studies that conceive diversity through its productive or generative capacities in all possible forms.

\section{Diversity as a Dispositif}

Recently, Mette Louise Berg and Nando Sigona (2013, p. 350) suggested that there are three different 'dimensions of diversity': diversity as a public narrative, as a social fact and as a policy. These dimensions are, according to Berg and Sigona interrelated. While insightful in many ways, their account remains wanting as it leaves unclear what these dimensions are interrelated as. Or in other words: It remains unclear what is, conceptually speaking, the larger "whole" within which different dimensions relate to each other. Such an absence precludes us from seeing how various dimensions of diversity that we might analytically differentiate between - as for example Berg and Sigona do - relate, link up and operate with, or along one another. In the research arena it remains difficult to see what it is that binds for example a study questioning how the acceptance of public discourse of diversity changes government's commitment to anti-racism (Berg and Sigona's diversity as a 'public narrative') with a piece of research that uses diversity as a neutral term describing a certain societal condition (diversity as a 'social fact'). This difficulty is in part due also to the lack or recognition that diversity is both a social and a social scientific concept (for the distinction see Bourdieu \& Wacquant, 1992), and to further differences 
in epistemologies that underlie concrete uses of the term diversity. This leads to a minefield of conceptual slippages in discussions about diversity.

Approaching diversity as a dispositif instead avoids these risks and provides a framework through which to see these relations. In fact, that is the overriding meaning of Foucault's notion of dispositif ${ }^{1}$. After all, dispositif is not "just" 'a thoroughly heterogeneous ensemble consisting of discourses, institutions, architectural forms, regulatory decisions, laws, administrative measures, scientific statements, philosophical, moral and philanthropic propositions' (Foucault, 1980). It is in fact the very 'system of relations that can be established between these elements' and the very nature of these relations and connections (Foucault, 1980). Approaching diversity conceptually as a dispositif then helps, in the very first place, to start accounting for the commonplace at-oddness and contradictoriness of practices, policies, uses and deployments of diversity that have been noted before (for example Faist, 2009; Vertovec, 2012). This applies likewise to diversity's incredible conceptual plasticity and flexibility - central to its governmental ascendance - both outside and inside academia.

And secondly, dispositif as a formation of 'generative social technologies which combine words and things in installing certain dispositions' (Bærenholdt, 2013, p. 24) in populations, stresses the productive, as well as contingent aspects of diversity. Namely, while dispositif might

\footnotetext{
${ }^{1}$ By using the original French term rather than the previously common English translation "apparatus" we follow a recent trend (for example Chaput \& Hanan, 2014; Bærenholdt, 2013; Pløger, 2008). As Chaput \& Hanan have argued, the term "apparatus" implies, inconsistently with Foucault, too much an enclosed system with a 'unified power structure' (2014, p. 9).
} 
effectuate a 'dominant strategic function' (Foucault, 1980), it does remain significantly receptive and malleable (Chaput \& Hanan, 2014). This means that even within a political context where (bar a few considered extremists) all are, or at least (have to) seem to be on board with "diversity", the proliferation of trainings, seminars and certificates, professional positions and higher education degrees, highly detailed business plans and manuals, diversity training centers and consulting businesses, new matrices of measurement, models for urban planners, conferences, workshops, and white papers and ordinances, deserves our constant inquisitiveness and sensitivity, both analytical and political. As mentioned above, for some the rise of diversity governance has brought about a depoliticization of issues of difference, in part because it treats them as a technical issue. But it might be more precise to say that diversity - while indeed missing an 'activist aspect' (Olwig, 2013, p. 479) - nonetheless remains political since there is 'always politics to the technical' (Elden, 2013).

Analytically we find it useful to start distinguishing disparate elements that make up diversity as a dispositif as belonging to the following fields: 1. ideational field of abstract schemes and conceptualizations of what diversity is about, that various actors, including scholars elaborate, argue about and promote; 2. technical field of specific tools and techniques, such as diversity training programs and certifications, statistical categories, or best practice manuals; and 3. actual social field of relations, interactions and dimensions of heterogeneity. It is this actually existing social heterogeneity that the ideational field conceptually attempts to array, and which the technical field - based on this mediating work of ideation - seeks to intervene into and arrange materially. In this book we bring together contributions from all these seemingly disparate varied strands of critical diversity research. We find this especially important, for to only present work 
on diversity management would in effect reduce diversity to its technical aspects - in the narrow meaning of the term technical. Likewise, if we only paid attention to actual social heterogeneities, that is the socio-demographic diversification of population, we would inadvertently reify diversity as simply a term describing pre-existing social reality. And finally, gathering only contributions focused on conceptions of diversity, whether in concrete political settings and times or in the form of academic theorizations, would one-sidedly dematerialize diversity. Before we turn to the discussion of those ensuing chapters, we, want to situate diversity in relation to multiculturalism.

\section{Diversity and multiculturalism}

Despite a sizeable agreement among many scholars of migration and multiculture regarding the diversity turn, diversity still remains at times not taken very seriously. It is, for example, sometimes understood as “just” a 'discursive strategy' (for example Bertossi, 2011, p.1569), and thus not much more than a new label for multiculturalism (see for example early Vertovec, 2009). To claim so, however, would be to disregard that language is not innocent or neutral and that all social reality is mediated through language. The terms we choose to deploy have 'complex histories' (Ahmed \& Swan, 2006, p. 96). They are bound up with distinct epistemic schemas, offering distinct imaginaries of actual social relations, and thus vary in their political effects (Ahmed \& Swan, 2006). As such it does matter that the term multiculturalism has become a taboo in the public arena over the past decade and instead diversity, in conjunction with "integration", have come to saturate the contemporary political landscape. 
Since (at least) the turn of the century, the term multiculturalism has become, politicallyspeaking, dead (for example Vertovec, 2010; Kymlicka, 2012; Vertovec \& Wessendorf 2010). That the denigration and rejection of multiculturalism amongst political actors has occurred across a wide spectrum of countries, regardless of whether a country had official multiculturalist policies in the past or not, is particularly telling in this respect. It thus might be heuristically valuable and empirically plausible to approach contemporary times as post-multiculturalist ${ }^{2}$ (see for example later Vertovec, 2010), although certainly not post-multicultural ${ }^{3}$. Unlike some of the early analyses of the 'retreat of multiculturalism' (Joppke, 2004), it is clear that many of the sensibilities and practices spurred by multiculturalism are indeed still detectable, especially in

${ }^{2}$ Some might question whether there was ever a 'multi-culturalist era, given that multiculturalism, as a state-sanctioned policy and public philosophy existed only in a relatively few national contexts. Yet multiculturalist ideas circulated across national contexts and borders, and became incorporated into political and social imaginaries of politicians, practitioners and activists working at local, sub-national scale in officially non-multiculturalist national settings. Such sub-nationally scaled institutions are not only often the most decisive ones for shaping everyday conditions of immigrant settlement and incorporation (for example Ehrkamp \& Leitner, 2003). Their ideas at times also scale up to influence political debates unfolding at the national scale. Arguably, at least some version of multiculturalism (for a list see for example Vertovec, 2010) held a status of a philosophical and governmental approach favored by most liberal political actors in most of the global north.

${ }^{3}$ Following Stuart Hall (2000) we differentiate between multiculturality as an actual social condition of culturally heterogeneous society on the one hand, and multiculturalism as a public philosophy or governmental framing of (cultural) difference on the other. 
local policies (Modood, 2011; Banting \& Kymlicka, 2010). More broadly we might discern a 'vibrancy of multicultural sensitivities' (Faist, 2009, p. 177), including in actually held notions of nationness, such as Britishness (Uberoi \& Modood, 2013). Yet the persistence of some practices associated with multiculturalism is hardly a proof that multiculturalism as a public philosophy remains still in place. To suggest so would be to rely on a 'misdirected synecdoche' (Collier, 2009, p. 97; see also Rose et al., 2006).

Even more importantly, contemporary governance of cultural "difference" is marked by a pronounced duality. Namely, governance through diversity is integrally intertwined with the imperative of "integration" (or "social cohesion" in some contexts, like the UK). For at least a decade now state officials and other governmental figures across the EU and in many other places have been stressing the obligation of immigrants to integrate into the national society, as well as, if not always as strongly, the obligation of the state to create tools and mechanisms that will assist immigrants in their integration efforts. The constant public invocation of the need to integrate is underpinned by a renewed emphasis on social cohesion and strengthening of national belonging, alleged lack thereof has been blamed on multiculturalism (for example Joppke, 2007; Grillo, 2007). While earlier assessments might have interpreted these developments as primarily a return to pre-multiculturalist assimilationism (Brubaker, 2001; Joppke, 2004; Vasta, 2007), the rise of the integrationist (and in the UK social cohesion) agenda is now being examined in its own right (for example Schinkel, 2011; Kaya, 2012; Joppke, 2007).

Still though, the burgeoning coupling of integration with diversity in contemporary governance goes less noticed. An exception has been Steven Vertovec (2009), who has observed the same 
proliferation of 'diversity-integration' injunctions in pronouncements, documents and measures across the EU in lieu of multiculturalism as we have. The 'striking' prominence (Holtug \& Mason, 2010, p. 407) of integration and social cohesion discourses and their attendant practices and logics goes namely hand in hand with the prominence and in fact a co-constitutive role of diversity in the governance of contemporary societies. We thus wish to avoid the conflation of diversity with multiculturalism, as it disregards the centrality that the renewed governmental centripetal investment in making a single entity out of its populations plays in the diversity governance.

Our suggestion of dispositif of diversity as distinct from multiculturalism serves primarily as a diagnostic device to allow us to approach diversity in its own right rather than as a proxy for something else. We do not wish to imply that there has been a clean-cut break, where diversity has completely replaced multiculturalism. This is after all not empirically possible, as different modalities of power 'are never simply successive elements, [where] the appearance of the new' causes 'the earlier ones to disappear' completely (Foucault, 2009, p. 22). Yet the new modality can and must be diagnosed through understanding how 'its major function at a given historical moment' has been to respond 'to an urgent need' (Foucault, 1980). And in case of diversity, or rather diversity-integration, it was devised as a response to the worries about and perceived limits of multiculturalism (see also Collier 2011, 2009). As such it can never be completely devoid of dealing with its traces, legacies and specters. Two of the contributions in the first part of the book are in fact great examples of such an engagement - not on part of bureaucrats or politicians but rather on part of academic experts. 
The ideational, the technical and the actual social

This volume gathers investigations within each constitutive analytical field of diversity outlined above, written from and across a number of disciplinary fields and from different geographicalpolitical contexts. While these three different aspects of diversity are always interwoven, they are separated here for reasons of analytical clarity. The first section, titled Framing Diversity, contains contributions that fall within the ideational field of diversity. In chapter 1, Paolo Boccagni offers a comprehensive critical analysis of main academic understandings and constructions of the concept of diversity in order to analyze its usefulness for future research. Boccagni argues that diversity indeed offers a specific heuristic perspective on societal differentiation that encompasses innovatively both a discourse of individualization and also the focus on societal meso-scale, or organizations. The chapter thus rejects, as we do in this introduction, an often-held assumption that diversity is simply multiculturalism reworked. In order to develop further, the chapter concludes, diversity studies should focus more on subjective understandings of diversity, especially on how different markers matter differently to different people. In the following chapter 2 Thomas Faist seeks to reformulate diversity in order to enhance its progressive potential. Starting from an observation about the wide political appeal of the framework of diversity, he namely calls for diversity to be understood as more than an organizational technique and rather as complex heterogeneities created and emerging through boundary-making processes of class, religion, gender, language and so on. Faist thus focuses on how cultural diversity turns into social inequality through boundary-shifting and boundaryblurring, identifying and examining four types of such social mechanisms: inclusion or exclusion through citizenship, exploitation, hierarchization, brokerage and opportunity hoarding. While the 
first two chapters exemplify critical conceptual engagements through which academic practice seeks to explicitly recalibrate both academic and public concepts of diversity, in the third chapter Mary Gilmartin offers a direct analysis of historically changing meanings of diversity in the political praxis in the Republic of Ireland, highlighting its malleability and contingency. While at the outset diversity was in this context conceived of as an equality-focused endogenous issue between the Catholics and the Protestants, during the times of prosperity that brought large numbers of immigrants to Ireland it was re-conceptualized as an issue of exogenous "cultural diversity", needing intercultural accommodation and "integration". In today's austerity era diversity shifted further and is seen primarily as "bad", as a potential problem. Even more problematically, Gilmartin stresses, it has come to mask broader processes of diversification, in particular the intensification of socio-economic inequality between the nationals and nonnationals.

With the second section, titled Managing and Practicing Diversity, the book shifts its focus towards the technical field of diversity. Chapter 4, 5 and 6 namely analyze contemporary deployments of various tools and practices of diversity as they relate to immigrant and minority population in concrete institutions and institutional settings. In chapter 4 Halleh Ghorashi and her collaborators start from their interest in understanding why diversity management programs fail to achieve lasting inclusion. Drawing on their research with the staff of philanthropic sector in Holland, the authors write from the context where diversity management is based more on a moral argument about exclusion and lack of equality rather than a business rationale. Yet, paradoxically, they suggest, the Dutch welfare state with its ideology of equality has inadvertently contributed to these failures because it has bred categorical thinking that sees 
immigrants as weak and disadvantaged. Such thinking, together with uncritical and unreflective approach to equality - conceptualized in Holland as sameness - has become deep-rooted, even amongst otherwise reflective staff members, as the chapter shows. Additionally, focus on equality has led to broad definitions of diversity that do not pay attention to historically embedded processes of exclusion that exclude some more than others. The chapter ends with a recommendation for organizations to adopt an alternative approach called "focus in context", characterized by a narrower definition of diversity focused on those differences that tend to matter most in the given context, combined with a more long-term commitment and willingness to effectuate deeper structural changes in organizations. The lack of deeper impacts in diversity programs is also at the center of chapter 5. Here Piotr Goldstein analyzes non-governmental organizations in two towns in the Balkans, Mostar and Novi Sad, where diversity-building has been one of the main components of post-war state- and society-building. The chapter identifies four different types of practices and narratives of diversity, highlighting how most organizations deploy superficial, "feel-good" or abstract celebrations of diversity that do not tackle difficult tensions existing on the ground. As they, however, tend to adopt their Western donors' focus on ethnic divisions in the Balkans, they are not innocuous. In fact, they reinforce a reductionist, that is ethnicized, view of local diversity. Goldstein also points out how the organization that very consciously avoided the discourse of "bridge-building" and diversity became the only one that succeeded in drawing together people across various differences and engage them in more meaningful and longer-lasting interactions. Chapter 6 rounds out this section by taking stock of the challenges faced by "diversity-inclusive", and especially multilingualism-attuned pedagogical praxis of institutions of higher education. Focusing on the EU, Cristina AllemannGhionda stresses that despite long-standing promotion of some form of diversity-attuned 
education by the EU, much of the educational practice continues to occur within the entrenched beliefs in mono-cultural and mono-linguistic socialization. This is so not only because of the strong persistence of national educational traditions that impacts or limits the implementation of the EU diversity agenda. As Allemann-Ghionda chapter points, European language policy itself entails multiple contradictions. Rather than a wide-spread acceptance of the very idea of inclusiveness of linguistic diversity, the EU embrace of multilingualism might be due to a reductionist, that is an economistic view of the value of linguistic diversity.

Finally, the last section, titled Social Relations of Diversity, analyzes actual social field of relations, interactions and dimensions of actual heterogeneity - the third sub-field of diversity from different vantage points. In chapter 7 Gill Valentine examines prejudice patterns of minority subjects vis-à-vis select "Others", focusing on the intersection of prejudice and inequality. Against the continued, if possibly eroding dominance of white majority-ethnic minority(ies) optic in much of diversity and migration studies, this chapter investigates complex intersectional personal identities and how they matter in encounters with "Others". It thus implicitly cautions against groupist conceptualizations of identities. Additionally, by stressing how one's identifications shift depending on particular temporal and spatial micro-contexts, this chapter also effectuates a more dynamic understanding of identifications. Such a deeper recognition of intersectionality and spatial-temporal dynamism of social identifications can, as Valentine argues, also empower people to reflect on some of the interplays between privilege and vulnerability, and thus change their ways of thinking. Chapter 8 likewise features a deployment of a more explicitly spatial approach to diversity. Here Nir Cohen examines how pre-existing social and cultural heterogeneity of a society, including the unequal power relations 
embedded in such heterogeneity, can become a catalyst for a failure to cope with, and popular protest against, further diversification of society through new, immigrant population. The chapter does this through an analysis of protests of Jewish residents of Middle Eastern and north African descent (Mizrahim), living in southern, socio-economically marginalized neighborhoods of Tel Aviv against the sub-Saharan migrants settling there. Rather than dismissing such protests simply as expressions of xenophobia, Cohen argues, locals' sensibilities are better understood through the concept of defensive urban citizenship. The chapter thus stresses broader context where Mizrahim feel excluded from the benefits of neoliberal urban economy - concentrated in northern Tel Aviv - and Israeli identity regime dominated by the Jews of European descent (Ashkenazim), while having to shoulder disproportionate burden of the city's growing urban diversity. Finally, in chapter 9 Liz Mavroudi and Louise Holt examine migration-related ethnic heterogeneity in school settings. They stress how schools are spaces with a possibly contradictory role in the age of diversity - namely one where they are supposed to promote both diversity and nationalism. While this is not inherently contradictory, nationalism has indeed been traditionally associated with exclusionary concern with, and promotion of purity and homogeneity. As Mavroudi and Holt underline, the deployment of such exclusionary nationalisms continues to unfold both in top-down as well as bottom-up fashion, as students and pupils - including those of migrant origin - often perform their national identities in equally exclusionary ways. What remains most troubling is the ability of educational institutions to often absorb the discourse of cultural diversity without a parallel expansion of inclusiveness. Mavroudi and Holt's concern with the relationship between nationalism and diversity carries over to the conclusion. Here we point out that despite the arrival of diversity as a governmental paradigm in many a nation-state many, in the general public as well as in the academe, continue to think of 
diversity and nation as opposed. Yet, as we stress, the "conundrum of diversity versus the nation" is a false one, beholden to (or originating from) a particular type of nationalism, that is, mono-culturalist nationalism. We advocate moving beyond normative reformulations of nationalism and towards analyses of the empirics of the everyday life, so as to expand a scalar imaginary of nationhood and thus avoid the false dichotomy that associates cities with diversity and nation with homogeneity. Even more importantly, we argue for a greater crossover between diversity and studies nationalism/nationhood. For if diversity studies fail to pay attention to the rethinking of nation that has been put forth in the latter, they might unintentionally help reproduce nation and nationalism as always exclusive and opposed to diversity. As a field it would thus remain short of its full potential.

Impasses, critiques and (towards) the ways out

The genuine concern with the potential of "diversity" is in fact one of the "deep themes" running through the length of this book. Most authors have been drawn to the analytical promise of diversity - elaborated in the greatest detail here by Boccagni - to move research on migration, and multicultural societies more broadly, away from ethnicity-centered conceptual framing that used to dominate such studies (see also for example Olwig, 2013). Equally, lesser focus on ethnicity within institutional politics could open up the doors to more progressive politics - and not just pertaining to migration - that take into account a whole range of identifications important in people's everyday lives. 
Yet as Valentine and Boccagni point out, even though diversity's analytical ambit does theoretically include all possible axes of social differentiation - including age, gender, sexuality it has until now continued to be shaped by (ethnic) majority-minority relations frame of thought. Diversity thus tends to be primarily understood in terms of ethno-cultural, religious and racial difference, especially those pertaining to migrant bodies, as stressed by Faist, Allemann-Ghionda or Ghorashi and her colleagues. Such a reductionist conception of diversity often overethnicizes societal relations, bearing at times an extremely high political cost, as clearest from the case of Western Balkans. This is especially so when reductionist conception of diversity is underwritten by static and hierarchical understandings of culture and ethnicity. Such still prevail in public life, despite anthropologists' decades-long insistence on cultures as plural, mutable and dynamic.

Static conception of culture is one of the deeper reasons why, despite the institutional incorporation of diversity agenda, institutions fail to become more fundamentally inclusive. Another one is an uncritical or lukewarm adoption of diversity agenda, especially, albeit not exclusively, in settings where it is considered a Western import, as stressed by Goldstein. The lack of reflexivity about diversity paradigm and discourse, and of more conscious approaches to diversity management - in part signs of a success of diversity "making it" as a governmental paradigm - tend to lead over time to a number of unintended paradoxical outcomes, described in detail in case-studies from the Balkans and Netherlands. Especially disconcertingly, Ghorashi with her collaborators show how constant and deep diversity-related reflexivity and selfreflexivity are difficult to achieve even amongst those already committed to the diversity cause. They urge us to understand how exhausting it is to constantly and on everyday basis leave behind one's comfort zones in order to achieve that. Importantly, such an exhaustion is more than likely 
to affect also how successfully intercultural sensitivity can be taught in schools, often seen maybe too optimistically according to Alleman-Ghionda as well as Mavroudi and Holt - as places of great hope for the transformation of societies. And finally, there is the neglect of socioeconomic difference in diversity governance. While socio-economic inequalities run often times very much along ethno-cultural divides - as highlighted here especially in Cohen's and Gilmartin's contributions - reductionist understandings of diversity as simply (ethno-)cultural diversity and application of narrow diversity programs further ignore, reify or legitimize social inequality, or even create socio-economic divisions, as Faist cautions.

At the same time, however, contributions gathered here offer concrete suggestions for getting out of the impasses of the diversity frame, in the academe as well as in the governance more broadly. The authors gathered insist, to borrow Gill Valentine's expression, on 'diversifying diversity', first of all within the academic research. This includes, in the first sentence, paying attention more persistently and systematically to the intersectional patterns of societal heterogeneities and axes of identity regimes, and their inequalities - as clearest from Valentine's, Faist's and Boccagni's chapters. Even when focusing primarily on the growing ethno-cultural diversification - historically at the forefront of migration and now also diversity studies - it is crucial to remain vigilant to how it always interlocks with other axes of societal differentiation. Most importantly, we must keep open to the fact that in many a time-space other-than-ethnic identifications and identities - always dynamic and relational - are more salient for given subjects than their ethnic ones. Diversification of diversity then also, in the second instance, takes seriously "endogenous" diversity - or cultural, religious, socio-economic and even "ethnic" heterogeneity - of national societies before the (most recent wave of) immigration, as showcased in pieces written by Cohen 
and Gilmartin. In order to help eradicate the widespread idea that it is migrants who "carry" diversity, diversity studies could even embrace more widely research projects that do not focus migrants or "ethnic" minorities of any kind in the first place. Equally, diversification of diversity studies should include investigations of a much wider array of geographic-political contexts that contribute to a more nuanced understanding of different modalities of diversity governance, despite sharing often similar core features. In fact - and this is the final, if a closely related point - many of the chapters included highlight the need for a socio-spatial approach to diversity. Explicitly spatial approach for example highlights and analyzes how governance often attempts to locate diversity - and the concomitant need for its management - at a particular scale and in concrete, and what it imagines to be 'bounded spaces' (Gilmartin, this volume), such as workplaces or schools. Yet understanding that such spaces are actually always 'porous spaces, connected globally' (Mavroudi \& Holt, this volume) reveals, at least partially, why such governance efforts fall flat. Similarly, constant awareness of how each subject's identifications are highly complex because they shift depending on particular spatial (as well as temporal) contexts (Valentine, this volume) forces us to approach diversities - or societal heterogeneities as relations and process (see also Olwig, 2013). These always co-constitute and are constituted by social spaces. Scrutinizing what specific spatial imaginaries particular formulations of diversity rely on then helps us understand diversity better, eventually leading to the much needed more progressive political reconceptualizations.

\section{References}

Ahmed, S. (2007). The language of diversity. Ethnic and Racial Studies, 30(2), 235-256. 
Banting, K., \& Kymlicka, W. (2010). Canadian Multiculturalism: Global Anxieties and

Bærenholdt, J. O. (2013). Governmobility: The Powers of Mobility. Mobilities, 8(1), 20-34.

Bourdieu, P., \& Wacquant, L. (1992). An invitation to reflexive sociology. Cambridge, UK:

Polity Press.

Ahmed, S., \& Swan, E. (2006). Introduction: Doing Diversity. Policy Futures in Education, 4(2), 96-100.Local Debates. British Journal of Canadian Studies, 23(1), 43-72.

Bell, J. M., \& Hartmann, D. (2007). Diversity in everyday discourse: the cultural ambiguities and consequences of "happy talk.” American Sociological Review, 72(6), 895-914.

Berg, M. L., \& Sigona, N. (2013). Ethnography, diversity and urban space. Identities. 20(4), $347-360$

Bertossi, C. (2011). National models of integration in Europe: A comparative and critical analysis. American Behavioral Scientist. 55(12), 1561-1580

Brubaker, R. (2001). The return of assimilation? Changing perspectives on immigration and its sequels in France, Germany, and the United States. Ethnic and Racial Studies, 24(4), 531-548. 
Chaput, C., \& Hanan, J. S. (2014). Economic Rhetoric as Taxis: Neoliberal governmentality and the dispositif of freakonomics. Journal of Cultural Economy.

Collier, S. J. (2011). Post-Soviet Social: Neoliberalism, Social Modernity, Biopolitics. Princeton: Princeton University Press.

Collier, S. J. (2009). Topologies of Power Foucault's Analysis of Political Government beyond 'Governmentality'. Theory, Culture and Society, 26(6), 78-108.

Cooper, D. (2004). Challenging diversity: Rethinking equality and the value of difference. Cambridge, UK: Cambridge University Press

Ehrkamp, P., \& Leitner, H. (2003). Beyond National Citizenship: Turkish Immigrants and the (Re)construction of Citizenship in Germany. Urban Geography, 24(2), 127-146.

Elden, S. (2013). Territory, the continental shelf, and ice - my comments to the ArcticNet conferene in Halifax. http://progressivegeographies.com/2013/12/16/territory-the-continentalshelf-and-ice-my-comments-to-the-arcticnet-conference-in-halifax/Last accessed January 5, 2015.

Eriksen, T. H. (2006). Diversity versus difference: Neo-liberalism in the minority debate. In R. Rottenburg, B. Schnepel, \& S. Shimada, The making and unmaking of difference (pp. 13-36). 
Bielefeld: Transaction.

Faist, T. (2009). Diversity - a new mode of incorporation? Ethnic and Racial Studies, 32(1), 171-190.

Foucault, M. (2009). Security, Territory, Population. Lectures at the Collège de France 19771978. New York: Picador.

Foucault, M. (1980). Power/Knowledge: selected interviews and other writings 1972-1977. New York: Pantheon Books.

Grillo, R. (2007). An excess of alterity? Debating difference in a multicultural society. Ethnic and Racial Studies, 30(6), 979-998.

Hall, S. (2000). Conclusion: the Multi-cultural Question. In B. Hesse, Un/Settled Multiculturalisms: Diasporas, Entanglements, Transruptions (pp. 209-240). London: Zed Books.

Herring, C., \& Henderson, L. (2012). From Affirmative Action to Diversity: Toward a Critical Diversity Perspective. Critical Sociology, 38(5), 629-643.

Holtug, N., \& Mason, A. (2010). Introduction: Immigration, diversity and social cohesion. Ethnicities, 10(4), 407-414. 
Jones, C. (2006). Falling between the Cracks: What Diversity Means for Black Women in Higher Education. Policy Futures in Education, 4(2), 145-159.

Joppke, C. (2007). Transformation of immigrant integration. World Politics, 59, 243- 273.

Joppke, C. (2004). The retreat of multiculturalism in the liberal state: theory and policy. British Journal of Sociology, 55(2), 237-257.

Kaya, A. (2012). Islam, Migration and Integration. Palgrave Macmillan.

Kraus, P. A., \& Sciortino, G. (2014). The diversities of Europe: From European modernity to the making of the European Union. Ethnicities, 14(4), 485-497.

Kraus, P. A. (2012). The politics of complex diversity: A European perspective. Ethnicities, $12(1), 3-25$.

Kymlicka, W. (2012). Comment on Meer and Modood. Journal of Intercultural Studies, 33(2), 211-216.

Lees, L. (2003). The ambivalence of diversity and the politics of urban renaissance: the case of youth in downtown Portland, Maine. International Journal of Urban And Regional Research, 27(3), 613-634. 
Modood, T. (2012). Post-immigration "difference" and integration. The case of Muslims in Western Europe. London, UK: The British Academy.

Modood, T. (2011). Multiculturalism and Integration: Struggling with Confusions. Florence, Italy: European University Institute Robert Schuman Centre for Advanced Studies.

Olwig, K. F. (2013). Notions and practices of difference: an epilogue on the ethnography of diversity. Identities, 20(4), 471-479.

Ostendorp, A., \& Steyaert, C. (2009). How different can differences be (come)?: Interpretative repertoires of diversity concepts in Swiss-based organizations. Scandinavian Journal of Management, 25(4), 374-384.

Pløger, J. (2008). Foucault's Dispositif and the City. Planning Theory, 7(1), 51-70.

Puwar, N. (2004). Thinking About Making a Difference. The British Journal of Politics \& International Relations, 6(1), 65-80.

Rodríguez-García, D. (2010). Beyond Assimilation and Multiculturalism: A Critical Review of the Debate on Managing Diversity. Journal of International Migration and Integration / Revue de l'integration et de la migration internationale, 11(3), 251-271. 
Rose, N., O'Malley, P., \& Valverde, M. (2006). Governmentality. Annual Review of Law and Social Science, 2, 83-104.

Schinkel, W. (2011). The nationalization of desire: Transnational marriage in Dutch culturist integration discourse. Focaal, 59, 99-106.

Swan, E. (2009). Commodity Diversity: Smiling Faces as a Strategy of Containment. Organization, 17(1), 77-100.

Swan, E., \& Fox, S. (2010). Playing the Game: Strategies of Resistance and Co-optation in Diversity Work. Gender Work and Organization, 17(5), 567-589.

Tatli, A. (2011). A Multi-layered Exploration of the Diversity Management Field: Diversity Discourses, Practices and Practitioners in the UK. British Journal of Management, 22(2), 238253.

Titley, G., \& Lentin, A. (Eds.). (2008). The politics of diversity in Europe. Strasbourg: Council of Europe.

Uberoi, V., \& Modood, T. (2013). Inclusive Britishness: A Multiculturalist Advance. Political Studies, 61(1), 23-41.

Vasta, E. (2007). From ethnic minorities to ethnic majority policy: Multiculturalism and the shift 
to assimilationism in the Netherlands. Ethnic and Racial Studies, 30(5), 713-740.

Vertovec, S. (2012). "Diversity” and the Social Imaginary. European Journal of Sociology, 53(03), 287-312.

Vertovec, S. (2010). Towards post-multiculturalism? Changing communities, conditions and contexts of diversity. International Social Science Journal, 61(199), 83-95.

Vertovec, S. (2009). Conceiving and researching diversity. Max Planck Institute for the Study of Religious and Ethnic Diversity (Working Paper 09-01).

Vertovec, S., \& Wessendorf, S. (Eds.) (2010). The Multiculturalism Backlash: European Discourses, Policies and Practices. London: Routledge.

Zanoni, P., \& Janssens, M. (2007). Minority Employees Engaging with (Diversity) Management: An Analysis of Control, Agency, and Micro-Emancipation. Journal of Management Studies, 44(8), 1371-1397.

Zanoni, P., \& Janssens, M. (2004). Deconstructing Difference: The Rhetoric of Human Resource Managers’ Diversity Discourses. Organization studies, 25(1), 55-74.

Zanoni, P., Janssens, M., Benschop, Y., \& Nkomo, S. M. (2010). Unpacking diversity, grasping inequality: Rethinking difference through critical perspectives. Organization, 17(1), 9-29. 
